\title{
Access to Information and Price Expectation Errors of Smallholder Farmers: Theory and Empirics
}

\author{
Mekbib G. Haile and Matthias Kalkuhl
}

\subsection{Introduction}

Producers use different information when making decisions concerning their economic activities. Past trends, outcomes in related markets, media reports, weather, and published forecasts are some of the information that farmers use in their resource allocation decisions (Just and Rausser 1981). The intrinsic feature of agriculture - the lag between production decision and output realization-makes these types of information indispensable to agricultural producers. Besides, agricultural production is inherently stochastic due to weather shocks, pest infestations, and other shocks, which affect the general market supply condition and therefore prices. Farmers need to form their expectations of market prices and potential yield for the upcoming harvesting season in order to make their production decisions. They invest in accessing and processing price and other market information, which they believe affects prices at harvesting time. This study assesses the information sources relevant to smallholder farmers and how efficiently farmers utilize the available information in their price expectation formations. This is important since modeling price expectations is an integral part of any agricultural supply response study (Moschini and Hennessy 2001).

In this study, we seek to empirically test the impact of access to information on the level of investment in information acquisition. Access to information is used synonymously with low costs of acquiring information to forecast future prices, which is notably a continuous rather than a discrete concept. Whereas ownership of information and communications technologies (ICT) and distance to markets serve as a measure of access to information (or costs of acquiring information), we use farmer realized price forecasting errors as a measure of the outcome

\footnotetext{
M.G. Haile $(\bowtie) \cdot$ M. Kalkuhl

Center for Development Research, University of Bonn, 53113 Bonn, Germany

e-mail: mekhaile@uni-bonn.de
} 
variable of interest. In particular, we seek to address the research question whether access to information (i.e., access to ICT and grain markets) results in a smaller price forecasting error of smallholder farmers in rural Ethiopia. Analyzing the distribution of smallholders' price expectations relative to realized prices assists policymakers in delivering information on price outlook and price risk management strategies. The main findings indicate that smallholders who have access to ICT and who reside closer to major grain markets are more likely to have smaller price forecasting errors. Public investment in both information and physical infrastructure that reduces the cost of accessing information is therefore vital for improving the precision of farmers' price expectations.

Several approaches have been applied to model expectations of agricultural producers. These include naïve expectation (Ezekiel 1938), whereby expected prices are assumed to be equal to the latest observed prices; adaptive expectation (Nerlove 1958), whereby farmers are assumed to revise their expectations depending on past errors; and rational expectation (Muth 1961), which assumes that expectations are consistent with the underlying market structure and that economic agents make efficient use of all available information. Other research has focused on modeling supply response using a quasi-rational price expectation (Holt and McKenzie 2003), which is consistent with price prediction from a reduced-form dynamic regression equation. Futures prices have also been used as proxies for price expectations (Gardner 1976).

Acquiring information is a common and critical feature of all of these expectation hypotheses. Because searching for and processing information are costly (Stigler 1961), it is unlikely that producers make use of all available information to form their price expectations (Orazem and Miranowski 1986). This is even more so in the context of subsistent smallholder farmers with limited access to credit and capital. Farmers therefore gather and process price and other market information that could potentially improve their price forecasts the most. A rational farmer invests in acquiring market information to the extent that the expected marginal benefit (in terms of more accurate price expectation) is greater or equal to the marginal cost of investing in acquiring the information. Ownership of information assets, such as a radio, a television, and a phone, and proximity to grain markets could potentially reduce the costs of investing in acquiring information. The government could also improve market efficiency by lowering the costs of access to information by providing market information as a public good through organized market information systems.

There is a large body of literature that investigates the effect of market information systems (MIS) or ICTs on the economic performances of farmers, traders, and consumers. Most of the existing empirical work has focused on the impact of MIS or ICTs on price dispersion between markets and sellers (Aker and Fafchamps 2015; Jensen 2007), price asymmetry between traders and farmers (Svensson and Yanagizawa 2009), traders' search behavior (Tack and Aker 2014), farmers bargaining power and selling prices (Mitchell 2011), consumption expenditures (Labonne and Chase 2009), and farmers' marketing choices (Tadesse and Bahiigwa 2015), among others (see Nakasone et al. 2014 for a recent review). The empirical 
evidence has been mixed regarding the effect of improved market price information on prices at micro level. Yet, there seems to be little evidence arguing against its positive effect on lowering price dispersion and search costs and improving agricultural market performance at a macro-scale (Nakasone et al. 2014). Access to better information through ownership of mobile phones, a radio, or a television could potentially assist farmers in making a more informed price expectation. This, in turn, helps them to make better decisions in terms of their crop choices, the amount to plant, land management efforts, and the amount and type of investment that they undertake in each cropping season. The present study therefore uses primary data from smallholders in Ethiopia to empirically evaluate the impact of access to information on farmers' price expectations.

The remainder of this chapter is organized as follows: The following section presents a theoretical model that studies the importance of market information in improving the price signal for farmers. Section 20.3 outlines the empirical model, the data, and some descriptive statistics. Section 20.4 presents and discusses the econometric results, and the last section concludes this chapter.

\subsection{Theoretical Model}

We employ a simple theoretical model to understand farmers' decision behaviors on production and information acquisition. The model consists of two stages: a production decision (second stage) and a decision about investment in information acquisition (first stage). The model is solved by backward induction. We therefore start with the second stage.

Consider a farmer who decides on the output level $y$ given a quadratic production cost $c(y)=\alpha y^{2}$. Crop prices are assumed to be random with mean $\mu$ and variance $\sigma^{2}$. Because production costs accrue before harvesting, the farmer maximizes discounted revenue from crop sales. With a discount rate of $r$ (cost of capital), the farmer maximizes expected profits:

$$
\max _{y} E\left[\frac{p y}{1+r}-c(y)\right]=\frac{E[p] y}{1+r}-c(y) .
$$

The first-order condition is $\frac{E[p]}{1+r}=c^{\prime}(y)=2 \alpha y$. With rational expectations (i.e., $E[p]=\mu$ ) the optimal production under uncertainty is given by $y^{*}=\frac{\mu}{2 \alpha(1+r)}$. Substituting $y^{*}$ into the expected profit function yields:

$$
E\left[\pi_{\mathrm{v}}\right]=\frac{\mu}{1+r}\left(1-\frac{1}{2 \alpha}\right)+\frac{\mu^{2}}{(1+r)^{2}} \frac{1}{4 \alpha},
$$

where the subscript $\mathrm{v}$ on $\pi_{\mathrm{v}}$ denotes profits under volatile prices. In case of no ex-ante uncertainty about prices, $E[p]=p$, the optimal production is $y^{*}=\frac{p}{2 \alpha(1+r)}$, 
and thus the expected profit $\pi_{\mathrm{c}}$ conditional on the fact that the farmer knows the random price ex-ante is

$$
E\left[\pi_{\mathrm{c}}\right]=E\left[\frac{p}{1+r}\left(1-\frac{1}{2 \alpha}\right)+\frac{p^{2}}{(1+r)^{2}} \frac{1}{4 \alpha}\right]=\frac{\mu}{1+r}\left(1-\frac{1}{2 \alpha}\right)+\frac{E\left[p^{2}\right]}{(1+r)^{2}} \frac{1}{4 \alpha} .
$$

With $E\left[p^{2}\right]=\sigma^{2}+\mu^{2}$, we obtain

$$
E\left[\pi_{\mathrm{c}}\right]=E\left[\pi_{\mathrm{v}}\right]+\frac{\sigma^{2}}{(1+r)^{2}} \frac{1}{4 \alpha} .
$$

Thus, farmers with access to perfect information on the harvest price are expected to have on average higher profits than farmers with uncertainty. The discrepancy increases with the magnitude of the uncertainty (variance $\sigma^{2}$ ).

In the first stage, the farmer chooses their level of investment in information acquisition, which results in acquisition of a perfect price signal regarding harvesting prices with probability $\rho$ or no signal with probability $1-\rho$. With the probability $1-\rho$, the price remains as uncertain as it would be without any investment in information acquisition (i.e., the farmer receives no signal regarding harvesting prices). The cost of investing in information acquisition is given by a twice differentiable function $\beta k(\rho)$, where $k(0)=0, k^{\prime}>0, k^{\prime \prime}>0, k(1)=\infty$ and $\beta$ is a scaling factor. Hence, $\rho$ measures the quality of the signal or the level of investment to obtain a perfect signal. The information investment decision involves choosing a $\rho \in[0,1]$ such that the expected profit-which is a weighted sum of the expected profit with certainty $E\left[\pi_{\mathrm{c}}\right]$ and the expected profit with uncertainty $E\left[\pi_{\mathrm{v}}\right]$ - is maximized after the costs of information acquisition are netted out, thus:

$$
\max _{\rho \in[0,1]} \rho E\left[\pi_{\mathrm{c}}\right]+(1-\rho) E\left[\pi_{\mathrm{v}}\right]-\beta k(\rho) .
$$

Given the profit in the second stage, the farmer chooses the optimal level of investment in information $\rho^{*}$ to maximize the expected profit in the first stage. After substituting the expected profit from the second stage into Eq. (20.5), the first-order condition is obtained as:

$$
\frac{\sigma^{2}}{(1+r)^{2}} \frac{1}{4 \alpha \beta}=k^{\prime}\left(\rho^{*}\right)
$$

Proposition 1 The optimal investment in information $\rho^{*}$ increases in $\sigma^{2}$ and decreases in $r, a$ and $\beta$. Thus, investment in information acquisition increases with price volatility, whereas it is negatively correlated with discount rates, costs of acquiring information, and production costs. 
Proof Calculating the total derivative in each parameter gives: $\frac{d \rho^{*}}{d \sigma^{2}}=$ $\frac{1}{(1+r)^{2} 4 \alpha \beta k^{\prime \prime}\left(\rho^{*}\right)}>0, \frac{d \rho^{*}}{d \alpha}=-\frac{\sigma^{2}}{(1+r)^{2} 4 \alpha^{2} \beta k^{\prime \prime}\left(\rho^{*}\right)}<0, \frac{d \rho^{*}}{d \beta}=-\frac{\sigma^{2}}{(1+r)^{2} 4 \alpha \beta^{2} k^{\prime \prime}\left(\rho^{*}\right)}<0$ and $\frac{d \rho^{*}}{d r}=-\frac{2 \sigma^{2}}{(1+r)^{3} 4 \alpha \beta k^{\prime \prime}\left(\rho^{*}\right)}<0$.

The magnitude of the forecasting error $V$ of the price expectation formation of the farmer can be measured by the expected squared deviations of the expected prices $p^{\mathrm{e}}$ from realized prices $p^{\mathrm{r}}$; thus $V=E\left[\left(p^{\mathrm{r}}-p^{\mathrm{e}}\right)^{2}\right]$. The farmer's expected price $p^{\mathrm{e}}$, in turn, depends on the level of information acquisition $\rho$ and is $p^{\mathrm{e}}=$ $\rho p^{\mathrm{r}}+(1-\rho) \mu$. It is the weighted sum of the realized price (revealed at probability $\rho$ ) and the unconditional mean $\mu$ of the random distribution of the price. Substituting $p^{\mathrm{e}}$ into $V$, we obtain $V=E\left[\left((1-\rho)\left(p^{\mathrm{r}}-\mu\right)\right)^{2}\right]=(1-\rho)^{2} E\left[\left(p^{\mathrm{r}}-\mu\right)^{2}\right]$, where $E\left[\left(p^{\mathrm{r}}-\mu\right)^{2}\right]=\sigma^{2}$ is the (unconditional) variance of the price.

Corollary 1 The magnitude of a farmer's forecasting error $V$ (measured as the squared deviation of the farmer's expected price conditional on the information acquired from the realized price) is $V=(1-\rho)^{2} \sigma^{2}$. It increases with $\sigma^{2}$ and decreases with $\rho$.

One particular implication of the corollary is that in case of no information acquisition, that is, $\rho=0$, the forecasting error is just the unconditional variance of the price series. For full information acquisition, $\rho=1$, the forecasting error will be zero. As $V$ decreases with $\rho$, the impact of the structural parameters on the forecasting error in the optimum $V^{*}$ has a sign opposite to that of the impact of these parameters on $\rho^{*}$. The exception is $\sigma^{2}$, which influences both the optimal $\rho^{*}$ and $V^{*}$ in opposite directions. ${ }^{1}$

This chapter employs empirical analyses to validate the theoretical model and to determine the sign and magnitude of the impacts of the structural parameters on the accuracy of price expectation formation. Because it is nearly impossible to observe investment in acquiring information per se, we explain the size of the price expectation error (or realized price forecasting error) with empirical data. The structural model parameters are linked to our empirical data as indicated in the last column of Table 20.1 .

\footnotetext{
${ }^{1}$ Formally, $\frac{\partial V^{*}}{\partial \sigma^{2}}=\left(\rho^{*}-1\right)\left[\left(\rho^{*}-1\right)+\frac{\sigma^{2}}{2 \alpha \beta(1+r)^{2} k^{\prime \prime}(\cdot)}\right]$ after substituting $\frac{d \rho^{*}}{d \sigma^{2}}$ from proposition 1 into the derivative of $V$ with respect to $\sigma^{2}$. As can be easily verified, $\frac{\partial V^{*}}{\partial \sigma^{2}}>0$ for sufficiently small values of $\sigma^{2}$ and $\frac{\partial V^{*}}{\partial \sigma^{2}}<0$ for sufficiently large values of $\sigma^{2}$.
} 
Table 20.1 Impact of structural parameters on the quality of the price signal

\begin{tabular}{|c|c|c|c|}
\hline \multirow[b]{2}{*}{$\begin{array}{l}\text { Parameter in the } \\
\text { theoretical model }\end{array}$} & \multicolumn{2}{|l|}{ Impact in optimum } & \multirow[b]{2}{*}{$\begin{array}{l}\text { Related explanatory variables } \\
\text { in empirical model }\end{array}$} \\
\hline & $\begin{array}{l}\text { On the quality of the } \\
\text { signal } \rho\end{array}$ & $\begin{array}{l}\text { On the forecasting } \\
\text { error } \mathrm{V}\end{array}$ & \\
\hline Cost of information $\beta$ & $\rho^{*}(\beta)<0$ & $V^{*}(\beta)>0$ & $\begin{array}{l}\text { Ownership of ICT, years of } \\
\text { schooling, distance to market, } \\
\text { distance to extension agents' } \\
\text { office }\end{array}$ \\
\hline Discount rate $r$ & $\rho^{*}(r)<0$ & $V^{*}(r)>0$ & $\begin{array}{l}\text { Discount rate, years of } \\
\text { schooling }\end{array}$ \\
\hline Production $\operatorname{costs} \alpha$ & $\rho^{*}(\alpha)<0$ & $V^{*}(\alpha)>0$ & $\begin{array}{l}\text { Distance to market, distance to } \\
\text { extension agents' office, } \\
\text { family labor }\end{array}$ \\
\hline Volatility $\sigma^{2}$ & $\rho^{*}\left(\sigma^{2}\right)>0$ & $V^{*}\left(\sigma^{2}\right) \gtrless 0$ & $\begin{array}{l}\text { Crop price volatility, crop } \\
\text { and/or village fixed effects }\end{array}$ \\
\hline
\end{tabular}

\subsection{Methods}

\subsubsection{Data and Descriptive Statistics}

Data for this study were obtained through a household survey. A random sample of 415 rural smallholders were selected from seven villages out of four different districts of Ethiopia, namely Kersa, Shashemene, Ada'a, and Debre Birhan Zuria. ${ }^{2}$ Adele Keke is a kebele ${ }^{3}$ selected from Kersa district and households in this village trade with the adjacent towns of Dire-Dawa, Harar, and Aweday. Smallholders in this kebele produce staple crops, typically corn and sorghum, and cash crops, like chat $^{4}$ and potato. We also interviewed households from four neighboring kebeles at the Debre Birhan Zuria district, which is $120 \mathrm{~km}$ northeast of Addis Ababa. The town of Debre Birhan is a nearby market for their grain production, which typically consists of barley, wheat, and horse beans, among others. Sirbana Godeti is a kebele that was selected in the Ada'a district and it is the major supplier of teff to the surrounding and Addis Ababa markets. Having relatively fertile soil, smallholders in this area also produce several leguminous crops and vegetables.

\footnotetext{
${ }^{2}$ The households in our sample were those selected for the widely used Ethiopian Rural Household Survey (EHRS), and detailed information on sampling techniques can be found from Dercon and Hoddinott (2004).

${ }^{3} \mathrm{~A}$ kebele is the smallest administrative unit in Ethiopia.

${ }^{4}$ Chat is a perennial cash crop and a mild stimulant that is commonly used in the southern and eastern parts of Ethiopia.
} 
Finally, we interviewed households from Turfe Ketchema, which is located about $12 \mathrm{~km}$ northeast from the town of Shashemene, where most of their marketing are conducted. The main crops that the smallholders in this survey area produce include potatoes, corn, wheat, barley, and teff.

The survey was conducted in April and May 2013, which was immediately before or at the onset of planting for the main "meher" season of 2014. This helped us obtain good information on planting time prices. Furthermore, the dataset provided detailed information on household demographics, asset holdings, production and consumption, purchases and sales, seasonal prices, information sources, among others. Data on sowing time prices from the nearby grain markets were obtained from the central statistical agency (CSA) of Ethiopia. Grain prices for the then upcoming harvesting prices, which were not known at the time of our survey, are obtained from three different enumerators who travelled to the respective markets to collect price information.

Following the liberalization of markets in Ethiopia in the early 1990s, prices have not only served as an incentive for farmers to produce more, but they have also become less predictable. Consequently, recent food price volatility has posed additional challenges to farmers in their production decisions. Information regarding input and output price developments, weather conditions, and input availability are hence crucial for the farmer to make a better production decision. Based on the survey data, most of the smallholder households perceive prices as highly unpredictable. About $85 \%$ of the households reported that output prices were likely to increase in the next one year, whereas the other $11 \%$ indicated that prices would have declined. Although most of the farmers $(87 \%)$ reported that changes in output prices (in a year) were more likely to range from a decrease by half to an increase by twice of the amount they predicted, the remaining households reported that prices could be outside this range.

Farmers form their price expectations based on information that they have access to. We asked the respondents two similar but subtly different questions regarding their sources of price information. First, we wanted to know the major sources of information for the market prices of their crops. Second, we asked them a more specific question with regard to what information they observe to predict the harvesting time price of the crop they chose to cultivate. Figure 20.1 shows the major responses. There are three main sources of price information for rural households in Ethiopia. Most of the smallholder farmers (54\%) visited close-by markets to sell or buy products and thereby gather price information for the commodities they are interested in, whereas about $45 \%$ of them got price information from their fellow farmers. About two-thirds of the households owned either a radio $(57 \%)$ or a mobile phone $(66 \%)$, or a television $(8 \%)$, and about a quarter of the rural households reported using these ICT tools as their sources of output price information. The 


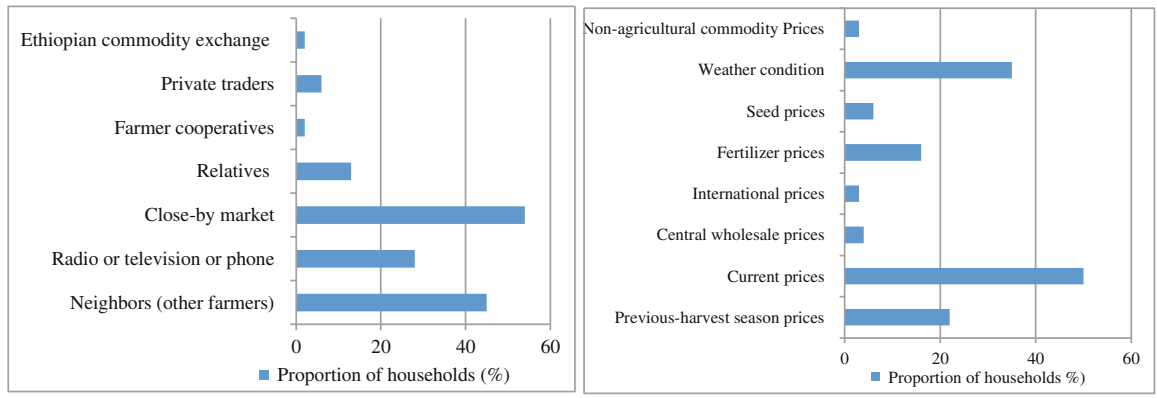

Fig. 20.1 Primary sources of price information (left) and relevant information for price expectation formation of smallholders (right) Note: respondents were allowed to give multiple responses

descriptive statistics also indicated that the Ethiopian Commodity Exchange (ECX) has not done enough to reach out rural smallholder farmers with price information. ${ }^{5}$

An interesting observation is that about half of the smallholders form their harvesting time price expectations based on the currently available price information. About a fifth of the respondents also considered prices from the past harvesting period in forming their price expectation. This may suggest that these households form their price expectations in line with the adaptive or naïve price expectation formation hypothesis. This is consistent with Chavas (2000), which indicated that close to half of the US beef markets were associated with the naïve expectation hypothesis. Nevertheless, other information such as weather, input prices, and central wholesale prices were reported by the smallholder farmers in our sample as relevant information in forming price expectation.

Subject to their access to information and their ability in data processing, farmers make their price predictions for the next harvesting period. The better the access farmers have to relevant price information, the more precise their price predictions are expected to be. This, in turn, results in a more efficient allocation of production resources. Table 20.2 presents the descriptive statistics for the smallholders in our sample, highlighting household characteristics, asset holdings, and other variables that could potentially affect farmers' data gathering and processing abilities that, in turn, influence their price expectation formations.

The summary statistics in Table 20.2 show a lot of similarities among the households from the four survey districts. On average, the household heads were in their mid-50s, and greater than two-third of them were married and male. The average family size (6.1) is slightly greater than the average household size in rural Ethiopia, which is 5.1 according to the household consumption and expenditure survey in 2010/2011 (CSA 2012). Although about $55 \%$ of the overall household

\footnotetext{
${ }^{5}$ Established in 2008 as a partnership between market actors, members of the exchange, and the government, the ECX is a marketing system that, among other things, aims to disseminate real-time market information to all market players.
} 
年

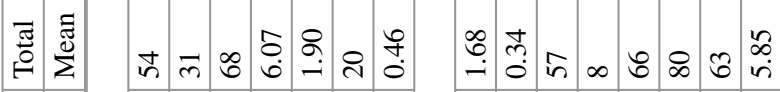

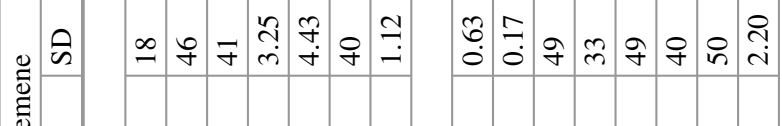

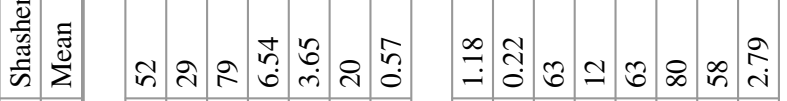

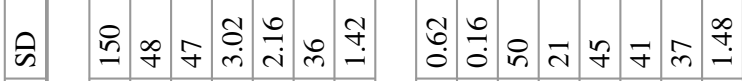

幽

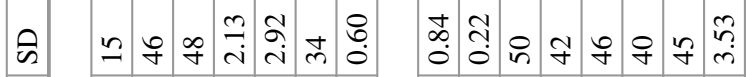

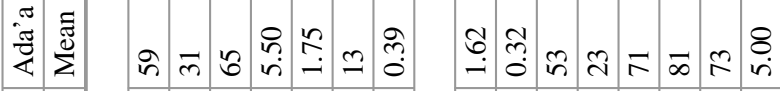

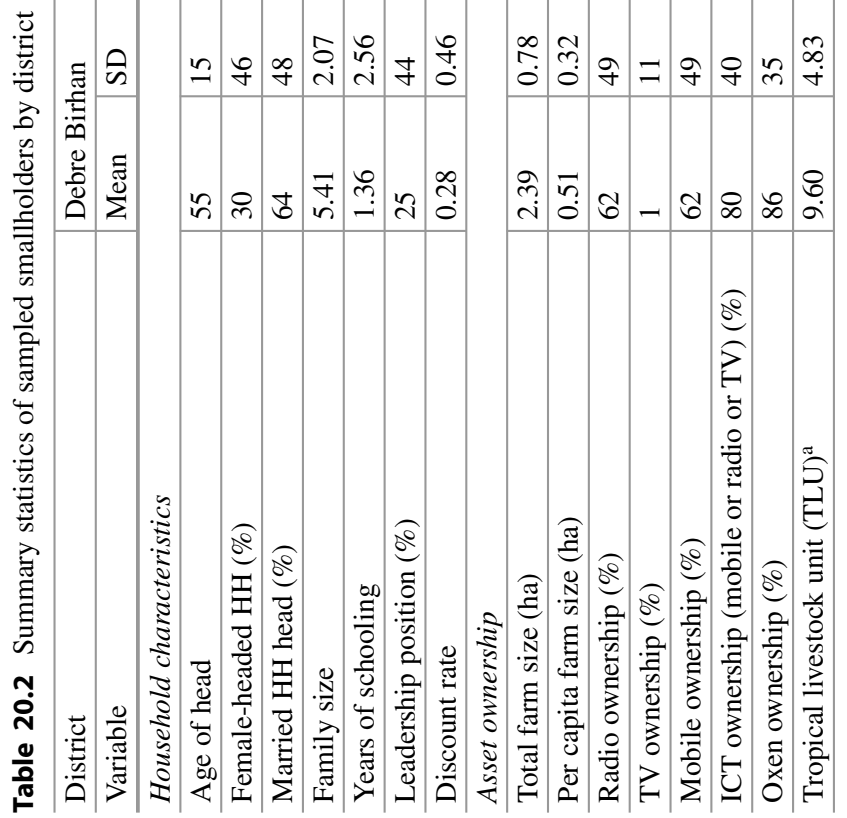




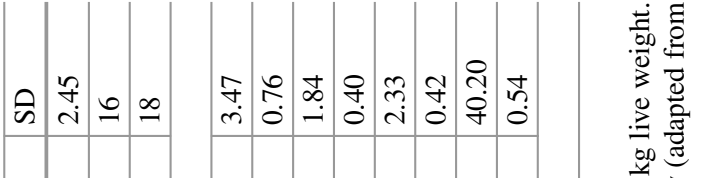

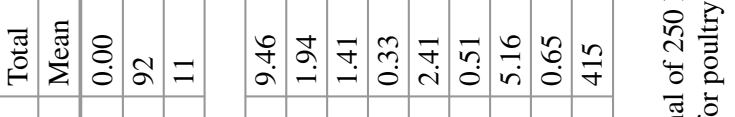

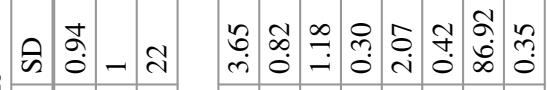

茴

สิ

뜨 글

胥

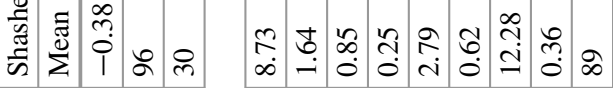

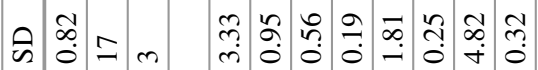

实

त त्ञ

离

בิ च

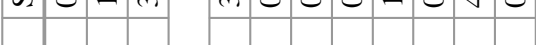

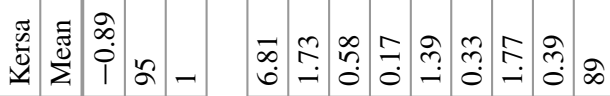

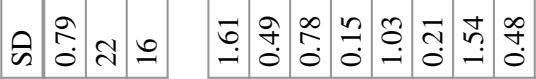

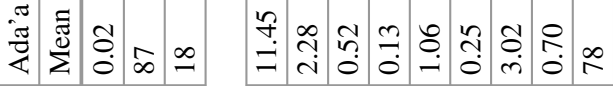

สี

ติ

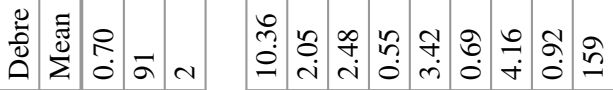

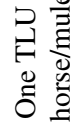

는

兽

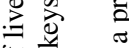

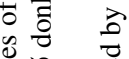

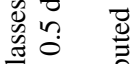

शे है

总离

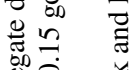

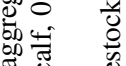

요 $\geqq$

马्ष

$\stackrel{乛}{=}$

窇离

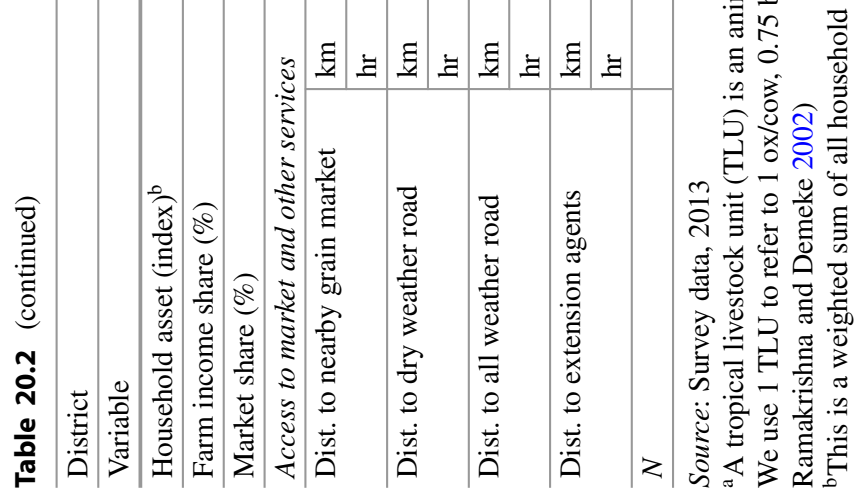


heads had some literacy skills through formal or informal education, the average family head had completed only the second grade. The smallholders in the sample had relatively large discount rates $(46 \%)$, which indicate severe liquidity problems. We measured discount rate using a survey question that elicits the minimum amount of money that a household head would have to be given in 6 months time in order to make them no different relative to a fixed amount given to them today.

The total land owned by the average smallholder was about 1.68 ha: smallholders in Debre Birhan district had, on average, slightly greater than 2 ha of land, whereas those in Kersa had slightly less than a hectare of land. The average per capita farm size was less than half a hectare. Besides, ownership of information assets such as mobile phone, radio, and television are very important in obtaining market, rainfall, and other information that could improve households' production decisions. The data showed that about $80 \%$ of the smallholders owned at least one ICT tool. ${ }^{6}$

Other indicators of access to market and information include distances from basic facilities. For instance, smallholder farmers are located on average $3 \mathrm{~km}$ away from an all-weather road and $10 \mathrm{~km}$ from a nearby grain market. Thus, the average farmer needs to walk about 1 and $2 \mathrm{~h}$ to access these facilities, respectively. As agriculture is the main activity in all districts, it is not surprising that off-farm income contributes less than $10 \%$ of the households' incomes. The degree of commercialization (market share of grains), as measured by the share of output sale from total production, is negligible in Kersa and Debre Birhan districts. This is mainly because chat is the main cash crop in Kersa, and sale of livestock is common in the latter. ${ }^{7}$

\subsubsection{Empirical Model}

We employed an econometric model to test part of the above theoretical model with the described household survey data. More specifically, we empirically assessed factors that determine the quality of the price signal, for example, whether households with better or cheaper access to information have more accurate price expectations. Our presumption was that a better price signal, as explained in the theoretical model, implies a more precise price expectation. To this end, we identified relevant variables that affect the precision of smallholders in their expectation formation. We obtained data on smallholders' expectations of harvesting season prices at planting time. This

\footnotetext{
${ }^{6}$ In this chapter, ICT ownership is the same as ownership of any of the three ICT assets, namely radio, television, or mobile phone.

${ }^{7}$ We calculated the market shares based on total sale and production of the six crops, namely teff, wheat, corn, sorghum, barley, and horse beans to be consistent with our empirical analysis.
} 
allowed us to compute a deviation of farmers' expected prices $\left(p^{\mathrm{e}}\right)$ from realized harvesting period output prices $\left(p^{\mathrm{r}}\right.$ or $\left.p_{t+1}\right)$ and use the deviation as a proxy for the quality of the price signal (i.e., as a measure of investment into information acquisition). Suppose PE denotes a measure of the price signal quality (henceforth prediction error), which is related to the variable $V$ in the theoretical model. A simple model to explain prediction error for a typical farmer $i$ can be specified as:

$$
\mathrm{PE}_{i}=\alpha+\gamma \mathrm{ICT}_{i}+\theta M_{i}+X^{\prime} \beta+\omega_{i}
$$

where PE is the deviation of each farmer's expected prices from the realized market prices - the outcome variable of interest; and the cost of information acquisition is captured by the two key variables of interest ICT and $M$. While ICT refers to ownership of information assets (radio, television, and phone), $M$ refers to distance to markets. Both variables capture costs of acquiring information. $X$ refers to a vector of all other explanatory variables that could potentially affect investment in information acquisition (and thus the level of precision in price expectation), such as household characteristics, discount rate, farm size, household wealth, and years of schooling; $\omega_{i}$ is an error term; and $\alpha, \gamma, \beta$ are parameters to be estimated.

As noted in footnote 6 , we used ownership of the abovementioned ICT tools as one of the proxies for access to information. In other words, we expect farmers to use their radios, televisions, or phones to access better information on variables that influence harvest-time prices, suggesting beneficial effect on their price forecasting ability. There are at least two concerns with this assumption. First, it is possible that farmers use the ICT tools for purposes other than accessing information (e.g., for luxury purposes). Richer farmers, who tend to have more of these information assets, can have better price forecasts based on other channels. Second, there is a possibility that farmers who do not own these information assets share common intrinsic characteristics, such as poor farming skills and management abilities, which are unlikely to be affected by having better market information.

We have taken a few measures to account for these issues. First, we controlled for covariates, such as the level of education, age, wealth proxy variables, and other farmer characteristics, to take into consideration farming experiences and management abilities. Second, we controlled for a variable that captures access to price information, which is an interaction between ownership of ICT and whether farmers use any of the ICT tools as a source of price information. It is worth noting here that farmers may (and are expected to) use their information assets to access more than just price information. This in turn may affect their price prediction. Therefore, ownership of ICT tools remains our main explanatory variable of interest that serves as a proxy to "access to information." Lastly, we calculated householdspecific average crop yield for our sample farmers using data from previous rounds of the Ethiopian rural household survey (ERHS). We specifically computed the average crop yield from the crop seasons of the ERHS data collected in 2004, 
2009, and from our survey in 2013. If ownership of a radio, television, or mobile phone is systematically related to farming or management skills and ability, then we would expect farmers without these tools to have relatively low crop yields. ${ }^{8}$ We included the average yield variable to control for these innate characteristics of farmers, which may also affect their price prediction error.

\subsubsection{Measuring Prediction Error 9}

We used four alternative, but related, measurements as proxies for smallholders' price prediction errors (or accuracy). Suppose $t$ and $t+1$ refer to the current sowing and the upcoming harvesting periods, whereby the former refers to the time of production decision. Therefore, $t$ refers to the time when farmers form their price expectations for the period $t+1$. Suppose also that $e$ denotes expectation; subscripts $c, i$, and $v$ denote crop-, farmer-, and village-specific prices, respectively; $n$ is the number of crops that a farmer grows and for which they report price expectations. The alternative measures of a farmer's price prediction error are defined as follows.

(a) Absolute mean price prediction error (AMPPE)

We measured the AMPPE as the absolute mean deviation of the farmer's expected prices from the realized prices in the respective grain markets for $n$ crops that the farmer grows

$$
\operatorname{AMPPE}_{i}=\frac{1}{n} \sum_{c}^{n}\left(\left|p_{c, t+1}-p_{i c, t}^{e}\right|\right) .
$$

(b) Relative mean price prediction error (RMPPE)

This is similar to the above measure except that we took the relative mean deviation of farmer's price expectations from the realized prices in the respective grain markets-instead of the absolute deviation.

$$
\operatorname{RMPPE}_{i}=\frac{1}{n} \sum_{c=1}^{n} \frac{\left(\left|p_{c, t+1}-p_{i c, t}^{e}\right|\right)}{p_{c, t+1}} .
$$

The above two measurements assume that a farmer gives equal weight to each crop in his price expectations. However, a farmer may invest more in acquiring better information regarding a crop that he produces for a market compared to a crop that he produces for home consumption. This, in turn, affects his price prediction accuracy of the respective crops. To take this into account, we calculated the deviation of market share-weighted expected prices from

\footnotetext{
${ }^{8} \mathrm{~A}$ simple linear regression of ownership of assets on past average crop yield supports this statement: ownership is strongly and positively correlated with crop yield.

${ }^{9}$ In this study, we refer to the quality of farmers' price expectations-that is, the deviation of farmers' expected prices from realized prices-alternatively as price prediction error (accuracy), forecasting error (accuracy), and expectation error (precision).
} 
similarly weighted realized prices. We used the market share of each crop to calculate price indices for each farmer and district. Using the farmers' reported and expected prices for sowing and harvesting periods, we obtain price indices for the respective seasons. Village-level price indices were similarly calculated using observed prices in the respective nearby grain markets. Furthermore, we normalized (both farmer- and district-specific) harvesting time price indices by the respective sowing time indices in order to consider the general trend of grain prices. Accounting for such price trends is important to overcome endogeneity in the estimation that may arise due to heterogeneities in the farmers' understanding of the overall inflation or deflation on their price predictions. Analogous to the two measures of prediction error mentioned above, we calculated the absolute and relative index price prediction error for each smallholder farmer.

(c) Absolute index price prediction error (AIPPE)

We calculated the AIPPE as an absolute deviation of indices of farmers' expected prices from the realized price indices in the respective markets/villages as

$$
\mathrm{AIPPE}_{i}=\left|\mathrm{NPI}_{v, t+1}-\mathrm{NPI}_{i, t}^{e}\right|
$$

where $\mathrm{NPI}_{t}=\frac{\sum_{c}^{n} \alpha_{c} p_{c, t}}{\sum_{c}^{n} \alpha_{c} p_{c, t-1}}$ refers to the normalized price index-where the denominator (sowing period price) is normalized at 100-for each village $v$ or for each household $i . \alpha_{c}$ refers to the market share of each crop.

(d) Relative index price prediction error (RIPPE)

RIPPE is calculated as the relative deviation of indices of farmers' expected prices from the realized price indices in the respective markets/villages.

$$
\mathrm{RIPPE}_{i}=\frac{\left(\left|\mathrm{NPI}_{v, t+1}-\mathrm{NPI}_{i, t}^{e}\right|\right)}{\mathrm{NPI}_{v, t+1}}
$$

Figure 20.2 illustrates how we measured PE using self-reported prices for the crops of interest in this study. The area in the dotted circle refers to realized $\left(p_{t+1}\right)$ and expected $\left(p^{\mathrm{e}}\right)$ prices of the new harvesting period. The latter are price expectations of farmers made at sowing time, $t$. The graph in the right panel is a replication of the corn example for better illustration. The vertical distance between the realized and expected price, indicated by the red arrow line, is the prediction error.

The above measures of price prediction error combine multiple crops that a farmer grows. This might result in an "averaging-out" effect if a farmer who has a large expectation error for one crop tends to have a small error for the other. In other words, these measures are inadequate if a farmer's price forecasts have 

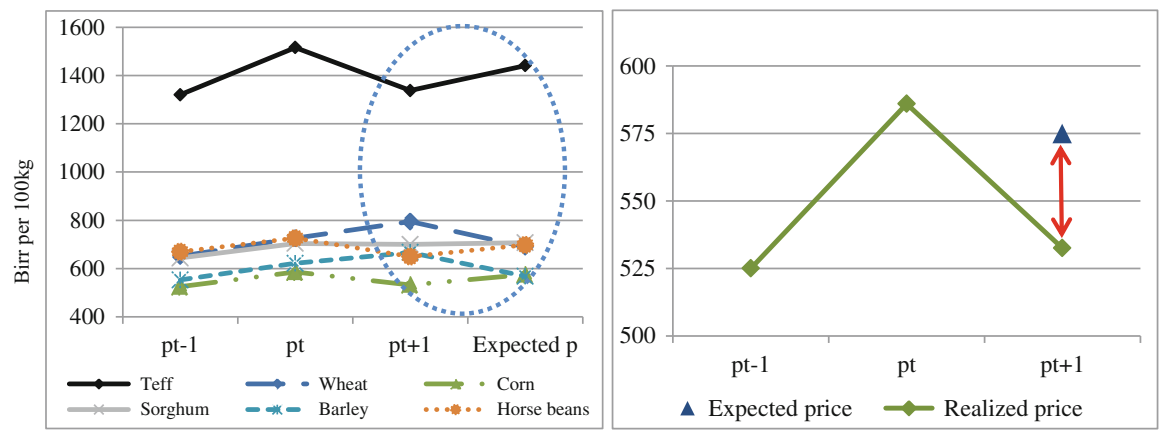

Fig. 20.2 Illustration of prediction error using self-reported prices

Table 20.3 Consistency of farmers' prediction errors between crops

\begin{tabular}{l|l|l}
\hline Crop-to-crop errors & Reg. coef. & Corr. coef. \\
\hline Barley and wheat & $\begin{array}{l}0.49 * * * \\
(0.10)\end{array}$ & $0.38 * * *$ \\
\hline Corn and sorghum & $\begin{array}{l}0.82 * * * \\
(0.16)\end{array}$ & $0.47 * * *$ \\
& & \\
\hline
\end{tabular}

Notes: Standard errors are in parentheses

** denotes statistical significance at the $1 \%$ level or less

large discrepancies across different crops. In order to shed some light on this, we computed regression and correlation coefficients between the magnitudes of individual farmer's forecasting errors for corn to that of sorghum and for wheat to that of barley. ${ }^{10}$

The coefficients in Table 20.3 illustrate a significant degree of consistency in prediction errors between crops for the same farmer. The farmers who made large errors in their corn price prediction also tended to make large errors for sorghum. This is also true for the expectation errors of farmers growing both wheat and barley. This hinted that the mean deviation would not cause the error for one crop to be offset by the error for another, suggesting also that crop diversification would not lead to any better resource allocation for the farmer.

Moreover, the data showed that the crop-specific price forecasting (prediction) errors, on average, range between 19 and $20 \%$ with comparable standard errors. This provided an additional clue for the absence of any large systematic difference in the difficulty of forecasting prices of different crops. There is also an economy of scale advantage for a farmer to invest in acquiring information on multiple crops.

\footnotetext{
${ }^{10} \mathrm{We}$ chose these crops because of the larger number of farmers producing the respective crop pairs.
} 


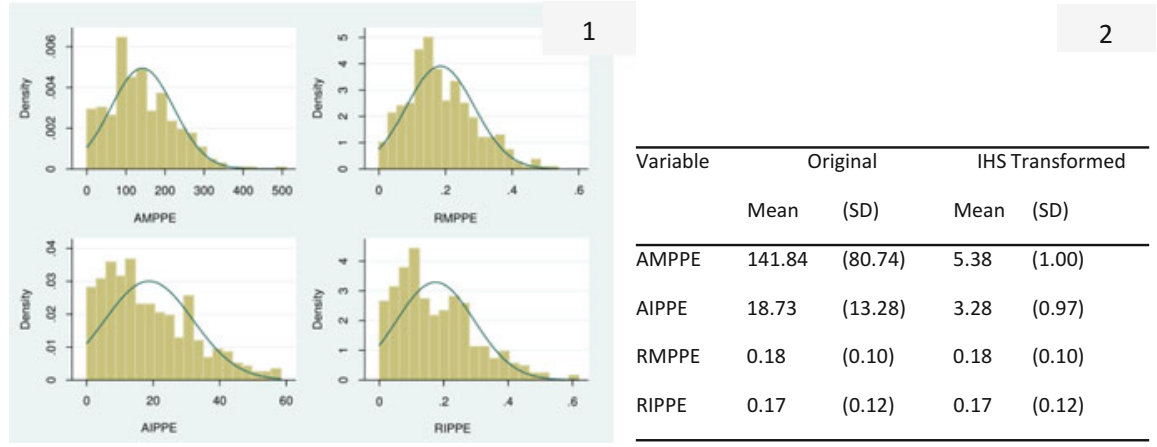

Fig. 20.3 Summary statistics and distribution of the dependent variable

\subsubsection{Estimation Technique}

The nature of the dependent variable (price prediction error), an absolute value of a narrowly dispersed variable, requires paying special attention to the estimation method used. Because the prediction error has a zero lower bound, it has a positively skewed distribution (Fig. 20.3, Panel 1). This variable has a relatively small range, $0-0.6$ with a mean close to zero, in the relative measures. As measured by RIPPE, for instance, the magnitudes of the prediction error made by smallholder farmers in our sample ranges from $0 \%$ to as far as $60 \%$, with a mean value of $17 \%$ (Fig. 20.3, Panel 2). This indicates that some farmers forecasted prices correctly, and the dependent variable has natural zero values. A quasi-maximum likelihood (QML) Poisson estimator would be appropriate in such situations (Cameron and Trivedi 2010; Nichols 2010; Wooldridge 2010). In fact, Santos Silva and Tenreyro (2006) argued that QML Poisson regression is preferred to an ordinary least squares (OLS) regression on a log-linear equation regardless of a count or a continuous dependent variable. ${ }^{11}$ Because the mean and the variance of our dependent variables are not equal - that is, the distribution is not Poisson-we needed to use the robust sandwich standard errors (Cameron 2009).

An OLS estimation can be used if the residuals are normally distributed. We transformed the alternative dependent variables using the inverse hyperbolic sine (IHS) method to get residuals that are approximately symmetrically distributed. ${ }^{12}$ We favored using IHS over logarithmic transformation as some households in our sample have zero prediction errors, the log of which is not defined. ${ }^{13}$ The IHS is a logarithmic-like transformation that retains zero and negative values, unlike

\footnotetext{
${ }^{11}$ We refer to an interesting Stata Blog post by Bill Gould about using a Poisson regression model (http://blog.stata.com).

${ }^{12}$ The IHS transformation of variable $x$ can be given as: ihs $(x)=\ln \left\langle\theta x+\left(\theta^{2} x^{2}+1\right)^{1 / 2}\right\rangle$ and the scale parameter $\theta$ is assumed to be unity in most applications.

${ }^{13}$ Because the dependent variable (when measured in relative terms) is not a proportion where values above one are infeasible, a logit transformation is not needed for an OLS estimation.
} 
logarithmic transformation, and has been applied in several studies (Bellemare et al. 2013; Burbidge et al. 1988; Moss and Shonkwiler 1993). This transformation allows us to interpret the OLS estimated coefficients as semi-elasticities. The marginal effects should be interpreted in percentage points in the case of the relative measures of the dependent variable (RMPPE and RIPPE).

\subsection{Results and Discussion}

Table 20.4 presents the estimation results of the maximum-likelihood Poisson regression model, specified as a generalized linear model (GLM) with a log-link function. The four columns differ in terms of the alternative measurements of prediction error, as discussed above. Although results are mostly consistent across the different specifications, we discuss the results from our preferred measure of prediction accuracy: the RIPPE. Besides accounting for the general grain price trend, this measure also weights crop prices with their respective market shares.

Controlling for access to ICT and grain markets, and other confounders, the estimated coefficients indicated that female-headed households had more accurate price expectations than male-headed households. Moreover, as expected a priori, households with an older (more experienced) head had statistically significant smaller forecasting errors. Not surprisingly, the precision of smallholders' price expectations was closely linked with the self-reported proxy for time preference (i.e., the discount rate). The results in Table 20.4 show that smallholders with higher discount rates, who tend to undervalue future gains and who therefore invest less in production but also information acquisition, have larger forecasting errors. This is consistent with the implication of the theoretical model.

As expected a priori, smallholders who had access to ICT such as radios, televisions, or mobile phones were more likely to make more precise price expectations than those who do not own any of these assets. Ownership of these assets enables them to access additional information on prices cheaply. More specifically, access to ICT was associated with about a $10 \%$ decrease in the conditional mean of a smallholder's prediction error $\left(100 \times\left[\mathrm{e}^{-0.11}-1\right]\right.$, in column [4] of Table 20.4). This means that the prediction error made by smallholder farmers who own any of the ICT tools was smaller by a factor of 0.89 than those who did not own any ICT tools, ceteris paribus. Smallholders who followed price information through radio or television or mobile telephony tended to forecast prices more accurately. This finding supports the theoretical model that indicates a negative impact of large information costs on the quality of the price signal. The interaction variable (ICT ownership and source of price information, ICT $\times$ InfoSource) is not statistically significant in all specifications. This indicates that information assets might have improved a farmer's price prediction accuracy mainly through access to non-price information, such as weather. 
Table 20.4 Factors that affect price prediction accuracy of smallholders

\begin{tabular}{|c|c|c|c|c|}
\hline Variables & AMPPE & AIPPE & RMPPE & RIPPE \\
\hline Male head & $\begin{array}{l}0.0328 * * * \\
(0.0120)\end{array}$ & $\begin{array}{l}0.1089 * * \\
(0.0460)\end{array}$ & $\begin{array}{l}0.0353 \\
(0.0300)\end{array}$ & $\begin{array}{l}0.1090 * * \\
(0.0430)\end{array}$ \\
\hline Age of head & $\begin{array}{l}-0.0004 \\
(0.0010)\end{array}$ & $\begin{array}{l}-0.0027 * * \\
(0.0010)\end{array}$ & $\begin{array}{l}-0.0007^{* *} \\
(0.0000)\end{array}$ & $\begin{array}{l}-0.0026^{* * *} \\
(0.0010)\end{array}$ \\
\hline Family size & $\begin{array}{l}-0.0108 * * * \\
(0.0030)\end{array}$ & $\begin{array}{l}0.0054 \\
(0.0110)\end{array}$ & $\begin{array}{l}-0.0112 * * * \\
(0.0020)\end{array}$ & $\begin{array}{l}0.0067 \\
(0.0100)\end{array}$ \\
\hline Head's years of schooling & $\begin{array}{l}0.0049 \\
(0.0030)\end{array}$ & $\begin{array}{l}0.0001 \\
(0.0060)\end{array}$ & $\begin{array}{l}0.0052 * * * \\
(0.0020)\end{array}$ & $\begin{array}{l}-0.0008 \\
(0.0050)\end{array}$ \\
\hline ICT & $\begin{array}{l}-0.0240 \\
(0.0300)\end{array}$ & $\begin{array}{l}-0.1117 * * * \\
(0.0410)\end{array}$ & $\begin{array}{l}-0.0557 * * \\
(0.0280)\end{array}$ & $\begin{array}{l}-0.1074 * * * \\
(0.0260)\end{array}$ \\
\hline ICT $\times$ InfoSource & $\begin{array}{l}-0.0344 \\
(0.0660)\end{array}$ & $\begin{array}{l}0.0885 \\
(0.0610)\end{array}$ & $\begin{array}{l}-0.0207 \\
(0.0470)\end{array}$ & $\begin{array}{l}-0.0724 \\
(0.0620)\end{array}$ \\
\hline Past average crop yield & $\begin{array}{l}0.0090 \\
(0.0310)\end{array}$ & $\begin{array}{l}-0.0525 \\
(0.0600)\end{array}$ & $\begin{array}{l}-0.0028 \\
(0.0230)\end{array}$ & $\begin{array}{l}-0.0478 \\
(0.0370)\end{array}$ \\
\hline Share of farm income & $\begin{array}{l}0.0822 \\
(0.0990)\end{array}$ & $\begin{array}{l}-0.0667 \\
(0.1690)\end{array}$ & $\begin{array}{l}0.0587 \\
(0.1830)\end{array}$ & $\begin{array}{l}-0.0429 \\
(0.1810)\end{array}$ \\
\hline Market share & $\begin{array}{l}-0.0929 \\
(0.0850)\end{array}$ & $\begin{array}{l}0.2323 \\
(0.1460)\end{array}$ & $\begin{array}{l}-0.1631 * * * \\
(0.0530)\end{array}$ & $\begin{array}{l}0.2591 \\
(0.1700)\end{array}$ \\
\hline Per capita livestock value & $\begin{array}{l}-0.0177 * * * \\
(0.0040)\end{array}$ & $\begin{array}{l}-0.0185^{* * *} \\
(0.0050)\end{array}$ & $\begin{array}{l}-0.0158 * * * \\
(0.0050)\end{array}$ & $\begin{array}{l}-0.0185^{* * *} \\
(0.0050)\end{array}$ \\
\hline Per capita farm size & $\begin{array}{l}-0.0307 \\
(0.1320)\end{array}$ & $\begin{array}{l}0.0061 \\
(0.1440)\end{array}$ & $\begin{array}{l}-0.0043 \\
(0.1490)\end{array}$ & $\begin{array}{l}0.0034 \\
(0.1340)\end{array}$ \\
\hline Dist. to grain market & $\begin{array}{l}-0.0047 \\
(0.0030)\end{array}$ & $\begin{array}{l}0.0301 * * * \\
(0.0040)\end{array}$ & $\begin{array}{l}-0.0029 \\
(0.0070)\end{array}$ & $\begin{array}{l}0.0296 * * * \\
(0.0050)\end{array}$ \\
\hline Dist. to extension agents' office & $\begin{array}{l}0.0042 \\
(0.0130)\end{array}$ & $\begin{array}{l}-0.0207 \\
(0.0150)\end{array}$ & $\begin{array}{l}0.0032 \\
(0.0100)\end{array}$ & $\begin{array}{l}0.0198 \\
(0.0190)\end{array}$ \\
\hline Discount rate & $\begin{array}{l}0.0350 * * * \\
(0.0080)\end{array}$ & $\begin{array}{l}0.0227 * * * \\
(0.0070)\end{array}$ & $\begin{array}{l}0.0378 * * * \\
(0.0060)\end{array}$ & $\begin{array}{l}0.0201 * * \\
(0.0090)\end{array}$ \\
\hline No. of crops & $\begin{array}{l}0.0706 \\
(0.0430)\end{array}$ & $\begin{array}{l}-0.1092 * * * \\
(0.0350)\end{array}$ & $\begin{array}{l}0.1038 * * * \\
(0.0220)\end{array}$ & $\begin{array}{l}-0.1042 * * * \\
(0.0260)\end{array}$ \\
\hline Constant & $\begin{array}{l}4.7818 * * * \\
(0.2980)\end{array}$ & $\begin{array}{l}3.9814 * * * \\
(0.6110)\end{array}$ & $\begin{array}{l}-1.7674 * * * \\
(0.2040)\end{array}$ & $\begin{array}{l}-0.8357^{* *} \\
(0.3950)\end{array}$ \\
\hline District dummies & Yes & Yes & Yes & Yes \\
\hline$N$ & 400 & 400 & 400 & 400 \\
\hline
\end{tabular}

Notes: Standard errors are bootstrapped and clustered in seven kebeles (villages) $*, * *, * * *$ denote statistical significance at $10 \%, 5 \%$, and $1 \%$ level, respectively

We included two proxy variables for wealth, per capita value of livestock and farm size, to take into account any possibility that richer smallholders may have had better price forecasts using information from channels other than the aforementioned information assets. The results confirmed that (regardless of ownership 
of information assets) wealthier farmers have better price forecasts, as indicated by the statistically significant and negative estimated coefficient of the per capita value of livestock value. The lagged historical crop yield variable, which captures poor farming skills and management ability of farmers, turned out to be statistically insignificant. Although farmers who do not own ICT may share such common farmer characteristics, these innate characteristics did not have a causal effect on their price forecasting accuracy.

Another important factor which determines the cost of access to information is the proximity of households to major local grain markets. The empirical finding is consistent with the theoretical model: the costs of acquiring information were higher for households located farther away from grain markets. All other factors remaining constant, halving the "effective" distance to a nearby grain market reduces the forecasting error of a farmer who is located at an average distance away from the market by about $14 \%\left(100 \times\left[\mathrm{e}^{-4.73 \times 0.03}-1\right]\right)$. This is consistent with the descriptive statistics as most households reported that they had usually visited nearby grain markets to obtain price information. In contrast, access to extension services-measured by distance from extension service offices-did not appear to be effective in providing information that helps smallholders improve their price forecasting performance. This may be partly explained by the training level of extension agents and the extent to which farmers trust the information they receive from agents.

We measured "access to ICT" by ownership of any of the information assets, namely radio, television, or mobile phone. It may, however, be necessary to investigate the differential impacts (if any) of each ICT. Table 20.5 presents the results using an exclusive ownership of mobile phone (column 2) and radio (column 3 ) as alternative measures of access to information. ${ }^{14}$ Column (1) in this table is the same as the last column in Table 20.4, and the dependent variable is RIPPE in all cases. The results suggest that mobile telephony alone played a statistically significant role in improving the price forecasting accuracy of farmers. However, the marginal effect of exclusive ownership of mobile phones is smaller than the effect of our preferred measure of information access (an estimated coefficient of $-0.05)$. Smallholders may use the information assets as a substitute or complement depending on several factors. The results also highlighted that ownership of a radio alone did not have a statistically significant effect on price prediction errors (column 3).

The last column in Table 20.5 controlled for interaction terms to test if the effects of access to ICT is conditional on some of the covariates (e.g., age and distance to market). Older household heads have more experience and are more likely to have better price forecasts, whereas younger heads do better if they have access to ICT. More specifically, the estimated coefficient of the interaction term of ICT and age of the head was positive (Column 4). The positive estimated coefficient of the

\footnotetext{
${ }^{14}$ Since only less than $10 \%$ of our sample owns a television $(8 \%)$ or all three assets $(7 \%)$, we only consider exclusive ownership of a mobile or a radio as alternative proxies for access to ICT.
} 
Table 20.5 Differential impacts of access to ICT on price prediction (RIPPE)

\begin{tabular}{|c|c|c|c|c|}
\hline Variables & (1) & (2) & (3) & (4) \\
\hline Male head & $\begin{array}{l}0.1090 * * \\
(0.0430)\end{array}$ & $\begin{array}{l}0.0937 * * \\
(0.0440)\end{array}$ & $\begin{array}{l}0.0973 * \\
(0.0520)\end{array}$ & $\begin{array}{l}0.0957 * * * \\
(0.0370)\end{array}$ \\
\hline Age of head & $\begin{array}{l}-0.0026^{* * *} \\
(0.0010)\end{array}$ & $\begin{array}{l}-0.0026^{* * *} \\
(0.0010)\end{array}$ & $\begin{array}{l}-0.0025^{*} \\
(0.0010)\end{array}$ & $\begin{array}{l}-0.0092^{* * *} \\
(0.0010)\end{array}$ \\
\hline ICT $\times$ Age & & & & $\begin{array}{l}0.0088 \text { *** } \\
(0.002)\end{array}$ \\
\hline Family size & $\begin{array}{l}0.0067 \\
(0.0100)\end{array}$ & $\begin{array}{l}0.0036 \\
(0.0060)\end{array}$ & $\begin{array}{l}0.0032 \\
(0.0060)\end{array}$ & $\begin{array}{l}0.0054 \\
(0.0060)\end{array}$ \\
\hline Head's years of schooling & $\begin{array}{l}-0.0008 \\
(0.0050)\end{array}$ & $\begin{array}{l}-0.0019 \\
(0.0040)\end{array}$ & $\begin{array}{l}-0.0013 \\
(0.0040)\end{array}$ & \begin{tabular}{|l|}
0.0021 \\
$(0.0040)$
\end{tabular} \\
\hline $\mathrm{ICT}^{\mathrm{a}}$ & $\begin{array}{l}-0.1074 * * * \\
(0.0260)\end{array}$ & $\begin{array}{l}-0.0513^{* *} \\
(0.0230)\end{array}$ & $\begin{array}{l}-0.0249 \\
(0.0430)\end{array}$ & $\begin{array}{l}-0.4494 * * * \\
(0.1540)\end{array}$ \\
\hline ICT $\times$ InfoSource & $\begin{array}{l}-0.0724 \\
(0.0620)\end{array}$ & & & $\begin{array}{l}-0.0727 \\
(0.0600)\end{array}$ \\
\hline Past average crop yield & $\begin{array}{l}-0.0478 \\
(0.0370)\end{array}$ & $\begin{array}{l}-0.0554 \\
(0.0640)\end{array}$ & $\begin{array}{l}-0.0521 \\
(0.0700)\end{array}$ & $\begin{array}{l}-0.0378 \\
(0.0700)\end{array}$ \\
\hline Share of farm income & $\begin{array}{l}-0.0429 \\
(0.1810)\end{array}$ & $\begin{array}{l}-0.1386 \\
(0.1690)\end{array}$ & $\begin{array}{l}-0.1236 \\
(0.1090)\end{array}$ & $\begin{array}{l}-0.0027 \\
(0.1510)\end{array}$ \\
\hline Market share & $\begin{array}{l}0.2591 \\
(0.1700)\end{array}$ & $\begin{array}{l}0.2433 \\
(0.1930)\end{array}$ & $\begin{array}{l}0.2406 \\
(0.1590)\end{array}$ & $\begin{array}{l}0.2594 \\
(0.1630)\end{array}$ \\
\hline Per capita livestock value & $\begin{array}{l}-0.0185^{* * *} \\
(0.0050)\end{array}$ & $\begin{array}{l}-0.0182 * * * \\
(0.0030)\end{array}$ & $\begin{array}{l}-0.0174 * * * \\
(0.0050)\end{array}$ & $\begin{array}{l}-0.0199 * * * \\
(0.0060)\end{array}$ \\
\hline Per capita farm size & $\begin{array}{l}0.0034 \\
(0.1340)\end{array}$ & $\begin{array}{l}-0.0222 \\
(0.1530)\end{array}$ & $\begin{array}{l}-0.0219 \\
(0.1060)\end{array}$ & $\begin{array}{l}-0.0036 \\
(0.1260)\end{array}$ \\
\hline Dist. to grain market & $\begin{array}{l}0.0296 * * * \\
(0.0050)\end{array}$ & $\begin{array}{l}0.0296 * * * \\
(0.0040)\end{array}$ & $\begin{array}{l}0.0296 * * * \\
(0.0040)\end{array}$ & $\begin{array}{l}0.0417 * * * \\
(0.0060)\end{array}$ \\
\hline ICT $\times$ dist. to market & & & & $\begin{array}{l}-0.0145^{*} \\
(0.008)\end{array}$ \\
\hline Dist. to extension agents' office & $\begin{array}{l}0.0198 \\
(0.0190)\end{array}$ & $\begin{array}{l}-0.0164 \\
(0.0100)\end{array}$ & $\begin{array}{l}-0.0175 \\
(0.0170)\end{array}$ & $\begin{array}{l}-0.0218 * \\
(0.0120)\end{array}$ \\
\hline Discount rate & $\begin{array}{l}0.0201 * * \\
(0.0090)\end{array}$ & $\begin{array}{l}0.0184 * * * \\
(0.0060)\end{array}$ & $\begin{array}{l}0.0184 * * * \\
(0.0070)\end{array}$ & $\begin{array}{l}0.0204 * * * \\
(0.0070)\end{array}$ \\
\hline No. of crops & $\begin{array}{l}-0.1042 * * * \\
(0.0260)\end{array}$ & $\begin{array}{l}-0.1078 * * * \\
(0.0280)\end{array}$ & $\begin{array}{l}-0.1109 * * * \\
(0.0290)\end{array}$ & $\begin{array}{l}-0.0970 * * * \\
(0.0370)\end{array}$ \\
\hline Constant & $\begin{array}{l}-0.8357 * * \\
(0.3950)\end{array}$ & $\begin{array}{l}-0.7023 \\
(0.5420)\end{array}$ & $\begin{array}{l}-0.7423 \\
(0.6500)\end{array}$ & $\begin{array}{l}-0.6864 \\
(0.6620)\end{array}$ \\
\hline District dummies & Yes & Yes & Yes & Yes \\
\hline$N$ & 400 & 400 & 400 & 400 \\
\hline
\end{tabular}

Notes: Standard errors are bootstrapped and clustered in seven kebeles (villages) $*, * *, * * *$ denote statistical significance a $10 \%, 5 \%$, and $1 \%$ level, respectively

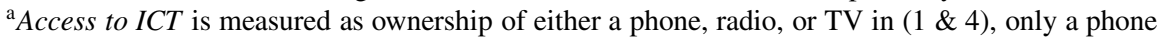
in (2), only a radio in (3) 
interaction term indicates that ownership of ICT tools has larger impacts on price prediction accuracy for households headed by younger farmers. This can be due to better knowledge of younger farmers with regard to using ICT tools and better understanding of the transmitted information.

Another interesting finding is that proximity to grain markets did not provide any more advantage in terms of predicting future prices as long as farmers have access to ICT. The estimated coefficient of the interaction term of ICT and distance from nearby grain markets was negative and statistically significant. In other words, the beneficial impact of ICT on price forecasting is stronger for smallholders located farther away from grain markets. Based on the estimated coefficients, the beneficial impact of access to ICT on price forecasting accuracy outweighs the detrimental impact of access to grain markets for farmers located as far as $15 \mathrm{~km}$ away from grain markets. This is because the interaction term indicates that prediction error increased by a factor of $\mathrm{e}^{0.03}=\left(\mathrm{e}^{0.04-0.01}\right)=1.03$ for every kilometer increase in distance to markets (an increase by this factor for every $15 \mathrm{~km}$ is approximately equal to the decrease in prediction error because of ownership of ICT). This suggests that ownership of information assets can serve as an alternative way to gain access to market information for farmers residing far away from grain markets but not for those located more than $15 \mathrm{~km}$ away. Ceteris paribus, simultaneously providing access to ICT and halving the "effective" distance to nearby grain markets, improved the prediction accuracy of farmers by as much as $45 \%\left(100 \times\left[\mathrm{e}^{\{-0.45+(-4.73 \times 0.03)\}}-1\right]\right)$.

\subsubsection{Robustness Checks}

We estimated Eq. (20.7) using an OLS method on the IHS-transformed variables. The results are reported in Tables 20.7 and 20.8 in Appendix. The OLS results were largely consistent with the ML Poisson estimation results. ${ }^{15}$ The control variables in our empirical model explained only a small but significant proportion of the variation in the farmers' forecasting errors. ${ }^{16}$ Ethiopia is one of the countries in which agricultural commodity prices have experienced significant variability in recent years (Rashid 2011; Tadesse and Guttormsen 2011). High price volatility reduces the accuracy of producers' and consumers' forecasts of crop prices (Binswanger and Rosenzweig 1986), even though the impact is ambiguous in our theoretical model. Given the stochasticity of output prices, a lucky farmer gets his expected

\footnotetext{
${ }^{15}$ Note that comparison of OLS and Poisson regression coefficients is inappropriate as they are interpreted differently. One can calculate the average marginal effects, $\sum_{i} \frac{\partial E\left(y_{i} \mid x_{i}\right)}{\partial x_{i j}}=\bar{y} \widehat{\beta}_{j}$, after the GLM regression and compare them with the corresponding OLS coefficients.

${ }^{16}$ The coefficients of determination, computed as a square of the correlation coefficients of the respective fitted and actual prediction error values, are comparable to the reported R-square in the OLS regression results.
} 
price close to the actual value. Thus, the 'luck factor' could probably explain some of the remaining variation of smallholders' forecasting errors. There also appears to be a widespread exchange of price and other information among households, thereby suggesting that the private information of a farmer who has the most timely and relevant information could be open to the public domain.

As a further robustness check, we employed a maximum likelihood estimation (MLE) technique with normal distribution to simultaneously estimate the mean price and its heteroskedastic variance term. In the mean equation, the realized price was estimated using the (farmer-reported) expected price. ${ }^{17}$ The residual $\varepsilon_{i} \sim N\left(0, \sigma_{i}^{2}\right)$ is the difference between expected and realized price. The variance of the residual is household-specific and normally distributed; it measures the forecasting error of the household. In the variance equation, the log variance was estimated conditional on the same set of explanatory variables $X$ as before. Hence, the maximum likelihood regression reads:

$$
\begin{gathered}
p_{i c, t+1}=\alpha+\beta p_{i c, t}^{e}+\varepsilon_{i}, \\
\ln \sigma_{i}=a_{c}+X^{\prime} \gamma .
\end{gathered}
$$

The maximum likelihood estimation results are reported in Table 20.6. We first observed that farmers have unbiased price expectations (at least in the year of our survey) as $\alpha$ was not statistically different from zero. Furthermore, the results for the variance regression were mostly consistent with both the QML Poisson and OLS estimation results.

\subsection{Conclusions}

A time lag between production decisions and output realization is intrinsic in agriculture; therefore, price expectations play a crucial role in the production, marketing, and agricultural technology adoption decisions of a farmer. The literature widely explores the effect of access to information-in particular access to market information systems, and to information and communication technologies-on a variety of economic variables, at both a macro and a micro level. The current study complements the existing literature by investigating the role of access to information on the precision of smallholders' price expectations. Producers invest money and time in searching for price and other information, which they believe would improve their price expectations. This process is costly for an individual farmer. The cost of information is therefore crucial for farmers in deciding on their level of investment

\footnotetext{
${ }^{17}$ This approach relies on empirical tests for unbiased or rational expectations, as typically used for assessing efficiency on commodity markets. See, e.g., Algieri and Kalkuhl (2014). Rational expectations are usually tested against $\alpha \neq 0$ and $\beta \neq 1$.
} 
Table 20.6 Factors that affect price prediction accuracy of smallholders, MLE

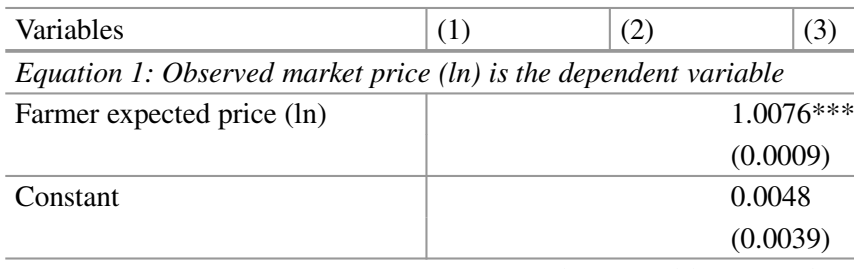

Equation 2: Ln (sigma) serves as a proxy for the natural log of prediction error

\begin{tabular}{|c|c|c|c|c|}
\hline Male head & $\begin{array}{l}0.0649 * \\
(0.0338)\end{array}$ & $\begin{array}{l}0.0560^{*} \\
(0.0335)\end{array}$ & $\begin{array}{l}0.0563 * \\
(0.0335)\end{array}$ & $\begin{array}{l}0.0712 * * \\
(0.0343)\end{array}$ \\
\hline Age of head & $\begin{array}{l}-0.0024 * * \\
(0.001)\end{array}$ & $\begin{array}{l}-0.0023^{* *} \\
(0.001)\end{array}$ & $\begin{array}{l}-0.0022 * * \\
(0.001)\end{array}$ & $\begin{array}{l}-0.0034 * \\
(0.0019)\end{array}$ \\
\hline ICT $\times$ age & & & & \begin{tabular}{|l}
0.0011 \\
$(0.0022)$
\end{tabular} \\
\hline Family size & $\begin{array}{l}-0.0073 \\
(0.0071)\end{array}$ & $\begin{array}{l}-0.0118^{*} \\
(0.0068)\end{array}$ & $\begin{array}{l}-0.0126^{*} \\
(0.0069)\end{array}$ & $\begin{array}{l}-0.0107 \\
(0.0072)\end{array}$ \\
\hline Head's years of schooling & $\begin{array}{l}0.0055 \\
(0.0056)\end{array}$ & \begin{tabular}{|l|}
0.0051 \\
$(0.0056)$
\end{tabular} & $\begin{array}{l}0.0056 \\
(0.0056)\end{array}$ & \begin{tabular}{|l|}
0.0045 \\
$(0.0057)$
\end{tabular} \\
\hline $\mathrm{ICT}^{\mathrm{a}}$ & $\begin{array}{l}-0.0882 * * \\
(0.0432)\end{array}$ & $\begin{array}{l}-0.0664 * * \\
(0.0302)\end{array}$ & $\begin{array}{l}-0.0265 \\
(0.0442)\end{array}$ & $\begin{array}{l}-0.0946^{* *} \\
(0.0409)\end{array}$ \\
\hline ICT $\times$ InfoSource & $\begin{array}{l}0.0198 \\
(0.0343)\end{array}$ & & & $\begin{array}{l}0.1682 \\
(0.1842)\end{array}$ \\
\hline Past average crop yield & $\begin{array}{l}-0.0227 \\
(0.0324)\end{array}$ & $\begin{array}{l}-0.0230 \\
(0.0321)\end{array}$ & $\begin{array}{l}-0.0234 \\
(0.0324)\end{array}$ & $\begin{array}{l}0.0281 \\
(0.0384)\end{array}$ \\
\hline Share of farm income & $\begin{array}{l}0.0653 \\
(0.2000) \\
\end{array}$ & $\begin{array}{l}-0.0402 \\
(0.1004)\end{array}$ & $\begin{array}{l}-0.0207 \\
(0.1002)\end{array}$ & $\begin{array}{l}0.0713 \\
(0.1126) \\
\end{array}$ \\
\hline Market share & $\begin{array}{l}-0.0591 \\
(0.1069)\end{array}$ & $\begin{array}{l}-0.1112 \\
(0.1055)\end{array}$ & $\begin{array}{l}-0.1129 \\
(0.1052)\end{array}$ & $\begin{array}{l}-0.0882 \\
(0.1099)\end{array}$ \\
\hline Per capita livestock value & $\begin{array}{l}-0.0120^{* *} \\
(0.0061)\end{array}$ & $\begin{array}{l}-0.0140^{* *} \\
(0.0057)\end{array}$ & $\begin{array}{l}-0.0135^{* *} \\
(0.0057)\end{array}$ & $\begin{array}{l}-0.0154 * * \\
(0.0062)\end{array}$ \\
\hline Per capita farm size & $\begin{array}{l}0.0326 \\
(0.0644)\end{array}$ & $\begin{array}{l}0.0129 \\
(0.0624)\end{array}$ & $\begin{array}{l}0.0115 \\
(0.0626)\end{array}$ & $\begin{array}{l}0.0296 \\
(0.0658)\end{array}$ \\
\hline Dist. to grain market & $\begin{array}{l}0.0080 * \\
(0.0045)\end{array}$ & $\begin{array}{l}0.0084 * \\
(0.0045)\end{array}$ & $\begin{array}{l}0.0087 * \\
(0.0045)\end{array}$ & $\begin{array}{l}0.0336 * * * \\
(0.0125)\end{array}$ \\
\hline ICT $\times$ dist. to market & & & & $\begin{array}{l}-0.0277 * * \\
(0.0129)\end{array}$ \\
\hline Dist. to extension agents' office & $\begin{array}{l}-0.0075 \\
(0.0065)\end{array}$ & $\begin{array}{l}-0.0047 \\
(0.0066)\end{array}$ & $\begin{array}{l}-0.0067 \\
(0.0065)\end{array}$ & $\begin{array}{l}-0.008 \\
(0.0065)\end{array}$ \\
\hline Discount rate & $\begin{array}{l}0.0304 \\
(0.0187)\end{array}$ & $\begin{array}{l}0.0222 \\
(0.0170)\end{array}$ & $\begin{array}{l}0.0243 \\
(0.0171)\end{array}$ & $\begin{array}{l}0.0246 \\
(0.0174)\end{array}$ \\
\hline No. of crops & $\begin{array}{l}0.2656 * * * \\
(0.0159)\end{array}$ & $\begin{array}{l}0.2668 * * * \\
(0.0161)\end{array}$ & $\begin{array}{l}0.2603 * * * \\
(0.0157)\end{array}$ & $\begin{array}{l}0.2670 * * * \\
(0.0159)\end{array}$ \\
\hline
\end{tabular}


Table 20.6 (continued)

\begin{tabular}{l|l|l|l|l}
\hline Variables & $(1)$ & $(2)$ & $(3)$ & $(4)$ \\
\hline Constant & $-2.3036 * * *$ & $-2.2150^{* * *}$ & $-2.2116^{* * *}$ & $-2.8668 * * *$ \\
& $(0.3390)$ & $(0.2726)$ & $(0.2747)$ & $(0.3285)$ \\
\hline District dummy & Yes & Yes & Yes & Yes \\
\hline Wald chi2 test $(p$-value $)$ & 0.000 & 0.000 & 0.000 & 0.000 \\
\hline$N$ & 2394 & 2400 & 2400 & 2394 \\
\hline
\end{tabular}

Notes: $*, * *, * * *$ denote statistical significance a $10 \%, 5 \%$, and $1 \%$ level, respectively

${ }^{a}$ Access to ICT is measured as ownership of either a phone, radio, or TV in $(1 \& 4)$, only a phone in (2), only a radio in (3)

in information acquisition. In this study, we employed access to ICT and distance to markets as measures of costs of acquiring information. The theoretical model, which has been explained in Sect. 20.2, unambiguously showed that the level of farmer's investment in acquiring information is negatively influenced by the costs of accessing information.

Using a primary survey dataset that elicits smallholders' price expectations for the next harvesting period, we empirically evaluated the impact of access to ICT and grain markets and other variables of interest on smallholders' price prediction accuracy. The findings suggest that farmers who have access to ICT and who reside closer to grain markets have smaller forecasting error margins, supporting the implications of the theoretical model. This calls for improving the information and physical infrastructure in rural areas of the country in order to reduce costs of obtaining information. The beneficial effect of access to ICT was larger for households that reside farther away from grain markets and for those headed by relatively younger farmers. From a policy perspective, these differential impacts are compelling as younger farmers and farmers living farther away from grain markets are among the households that hold larger potential for increasing agricultural productivity in the country. This is because farm plots that are located very close to markets are highly degraded, and older farmers are less willing to adopt new technologies.

In agreement with the theoretical model, the empirical findings showed that farmers with higher discount rates were more likely to have larger forecasting errors. This has implications for assisting farmers in reducing future price and income uncertainties, and for enhancing their risk-management strategies. There are some institutions such as the Ethiopian Grain Trade Enterprise (EGTE), the Ethiopian Commodity Exchange (ECX), and the Agricultural Transformation Agency (ATA) that could potentially improve smallholders' access to market information in the country. These institutions may assist farmers in providing and disseminating reliable and timely central wholesale prices.

Access to extension agents did not have any statistically significant contribution to improving price prediction accuracy of farmers in our sample. Extension agents in Ethiopia serve more as a source of credit and inputs rather than a source of information on optimal input use and market information (Spielman et al. 2012). 
Extension service, with agents who have valuable market information and better knowledge of how to use inputs than rural farmers, is important for improving the production decision of smallholders. However, past research has shown that Ethiopian extension agents have little practical experience and poor communication skills (Belay and Abebaw 2004). This could explain why farmers may not trust extension agents and hence do not adopt their advice. Because the Ethiopian government is expanding the extension service program throughout the country, it is important to consider disseminating reliable price and market information through extension services in the country to farmers with limited access to such information.

Acknowledgments We would like to thank Maximo Torero for his helpful comments on an earlier version of this chapter and for some crucial underlying ideas for the theoretical model framework. We also thank Justice Tambo, Jan Brockhaus, and Lukas Kornher for helpful discussions and Tobias Heimann for his assistance in the research. The authors are grateful for the financial support of the Federal Ministry of Economic Cooperation and Development of Germany (BMZ) for the research project "Volatility in Commodity Markets, Trade Policy, and the Poor" as well as for the financial support of the European Commission for the FOODSECURE project.

\section{Appendix. OLS Estimation Results}

Table 20.7 Factors that affect price prediction accuracy of smallholders

\begin{tabular}{l|l|l|l|l}
\hline \multicolumn{2}{l}{ Dependent variable: relative mean/index price prediction error } \\
\hline Variables & AMPPE & AIPPE & RMPPE & RIPPE \\
\hline Male head & $0.1121 * *$ & $0.1590 * *$ & 0.0059 & $0.0186 * * *$ \\
& $(0.0551)$ & $(0.0622)$ & $(0.0037)$ & $(0.0043)$ \\
\hline Age of head & 0.0009 & $-0.0039 *$ & -0.0001 & $-0.0004 * *$ \\
& $(0.0014)$ & $(0.0021)$ & $(0.0001)$ & $(0.0002)$ \\
\hline Family size & -0.0068 & 0.0029 & $-0.0020 * * *$ & 0.0009 \\
& $(0.005)$ & $(0.008)$ & $(0.0006)$ & $(0.0008)$ \\
\hline Head's years of schooling & 0.004 & $-0.0168 * * *$ & $0.0012 * * *$ & -0.0004 \\
& $(0.0085)$ & $(0.0060)$ & $(0.0004)$ & $(0.0006)$ \\
\hline ICT & $-0.0682 * * *$ & -0.0435 & $-0.0102 * *$ & $-0.0182 * * *$ \\
& $(0.0245)$ & $(0.1080)$ & $(0.0043)$ & $(0.0068)$ \\
\hline ICT $\times$ InfoSource & -0.0474 & 0.0176 & -0.0028 & 0.0123 \\
& $(0.0757)$ & $(0.1569)$ & $(0.0097)$ & $(0.0092)$ \\
\hline Past average crop yield & $-0.1102 *$ & -0.0194 & -0.0003 & -0.0085 \\
& $(0.0613)$ & $(0.1254)$ & $(0.0064)$ & $(0.0089)$ \\
\hline Share of farm income & -0.1538 & -0.0625 & 0.0085 & -0.0092 \\
\hline Market share & $(0.2139)$ & $(0.2765)$ & $(0.0275)$ & $(0.0298)$ \\
\hline & -0.1091 & 0.0273 & $-0.0308 * * *$ & 0.0328 \\
& $(0.1015)$ & $(0.1788)$ & $(0.0116)$ & $(0.0315)$ \\
\hline
\end{tabular}


Table 20.7 (continued)

\begin{tabular}{l|l|l|l|l}
\hline Dependent variable: relative mean/index price prediction error \\
\hline Variables & AMPPE & AIPPE & RMPPE & RIPPE \\
\hline Per capita livestock value & $-0.0132^{* * *}$ & -0.0079 & $-0.0031^{* * *}$ & $-0.0026^{* * *}$ \\
& $(0.0051)$ & $(0.0097)$ & $(0.001)$ & $(0.0007)$ \\
\hline Per capita farm size & 0.0044 & 0.0264 & 0.0001 & 0.0009 \\
& $(0.1041)$ & $(0.1234)$ & $(0.0245)$ & $(0.0254)$ \\
\hline Dist. to grain market & $-0.0158^{* *}$ & $0.0261^{* *}$ & -0.0005 & $0.0054^{* * *}$ \\
& $(0.0076)$ & $(0.0130)$ & $(0.0006)$ & $(0.0012)$ \\
\hline Dist. to extension agents' office & 0.0111 & -0.0268 & 0.0008 & -0.0039 \\
& $(0.0151)$ & $(0.0432)$ & $(0.0022)$ & $(0.0033)$ \\
\hline Discount rate & $0.1011^{* * *}$ & $-0.0376^{* * *}$ & $0.0072^{* * *}$ & $0.0031^{* * *}$ \\
& $(0.0184)$ & $(0.0109)$ & $(0.0014)$ & $(0.0010)$ \\
\hline No. of crops & $0.1169^{* *}$ & $-0.1324 * *$ & $0.0208^{* * *}$ & $-0.0169^{* * *}$ \\
& $(0.0484)$ & $(0.0520)$ & $(0.0057)$ & $(0.0060)$ \\
\hline Constant & $6.1571^{* * *}$ & $4.2603^{* * *}$ & $0.1646 * * *$ & $0.3296^{* * *}$ \\
& $(0.4752)$ & $(1.1827)$ & $(0.0623)$ & $(0.0925)$ \\
\hline District dummies & Yes & Yes & Yes & Yes \\
\hline Wald chi2 test $(p$-value) & 0.00 & 0.00 & 0.00 & 0.00 \\
\hline Root MSE & 0.912 & 0.913 & 0.095 & 0.111 \\
\hline Adjusted $R$-square & 0.20 & 0.15 & 0.15 & 0.20 \\
\hline$N$ & 400 & 400 & 400 & 400 \\
\hline$N$ & & & &
\end{tabular}

Notes: Standard errors are bootstrapped and clustered in seven kebeles (villages)

$*, * *, * * *$ denote statistical significance at $10 \%, 5 \%$, and $1 \%$ level, respectively. Note that since the dependent variable is either IHS-transformed (APPME \& AIPPE) or expressed as a ratio (RMPPE \& RIPPE), the coefficients can be considered as economically relevant

Table 20.8 Differential impacts of access to ICT on price prediction

\begin{tabular}{l|l|l|l|l}
\hline Variables & $(1)$ & $(2)$ & $(3)$ & $(4)$ \\
\hline Male head & $0.0186^{* * *}$ & $0.0164 * *$ & $0.0169 * * *$ & $0.0171^{* *}$ \\
& $(0.0043)$ & $(0.0070)$ & $(0.0062)$ & $(0.0087)$ \\
\hline Age of head & $-0.0004^{* *}$ & $-0.0004^{* * *}$ & $-0.0004^{* *}$ & $-0.0017^{* * *}$ \\
& $(0.0002)$ & $(0.0001)$ & $(0.0002)$ & $(0.0002)$ \\
\hline ICT $\times$ age & & & & $0.0016^{* * *}$ \\
& & & & $(0.0002)$ \\
\hline Family size & 0.0009 & 0.0005 & 0.0004 & 0.0008 \\
& $(0.0008)$ & $(0.0009)$ & $(0.0013)$ & $(0.0014)$ \\
\hline Head's years of schooling & -0.0004 & -0.0006 & -0.0005 & 0.0000 \\
& $(0.0006)$ & $(0.0006)$ & $(0.0008)$ & $(0.0005)$ \\
\hline ICT & $-0.0182^{* * *}$ & $-0.0082^{*}$ & -0.0047 & $-0.0851^{* * *}$ \\
& $(0.0068)$ & $(0.0045)$ & $(0.0050)$ & $(0.0233)$ \\
\hline
\end{tabular}


Table 20.8 (continued)

\begin{tabular}{|c|c|c|c|c|}
\hline Variables & (1) & $(2)$ & (3) & (4) \\
\hline Past average crop yield & $\begin{array}{l}-0.0085 \\
(0.0089)\end{array}$ & $\begin{array}{l}-0.0092 \\
(0.0106)\end{array}$ & $\begin{array}{l}-0.0086 \\
(0.0080)\end{array}$ & $\begin{array}{l}-0.0070 \\
(0.0105)\end{array}$ \\
\hline Share of farm income & $\begin{array}{l}-0.0092 \\
(0.0298)\end{array}$ & $\begin{array}{l}-0.0263 \\
(0.0284)\end{array}$ & $\begin{array}{l}-0.0241 \\
(0.0205)\end{array}$ & $\begin{array}{l}-0.0046 \\
(0.0284)\end{array}$ \\
\hline Market share & $\begin{array}{l}0.0328 \\
(0.0315)\end{array}$ & $\begin{array}{l}0.0326 \\
(0.0285)\end{array}$ & $\begin{array}{l}0.0324 \\
(0.0270)\end{array}$ & $\begin{array}{l}0.0332 \\
(0.0212)\end{array}$ \\
\hline Per capita livestock value & $\begin{array}{l}-0.0026^{* * *} \\
(0.0007)\end{array}$ & $\begin{array}{l}-0.0026^{* * *} \\
(0.0006)\end{array}$ & $\begin{array}{l}-0.0025^{* * *} \\
(0.0007)\end{array}$ & $\begin{array}{l}-0.0028^{* * *} \\
(0.0009)\end{array}$ \\
\hline Per capita farm size & $\begin{array}{l}0.0009 \\
(0.0254)\end{array}$ & $\begin{array}{l}-0.0022 \\
(0.0259)\end{array}$ & $\begin{array}{l}-0.0019 \\
(0.0155)\end{array}$ & $\begin{array}{l}0.0012 \\
(0.0249)\end{array}$ \\
\hline Dist. to grain market & $\begin{array}{l}0.0054 * * * \\
(0.0012)\end{array}$ & $\begin{array}{l}0.0054 * * * \\
(0.0009) \\
\end{array}$ & $\begin{array}{l}0.0054 * * * \\
(0.0009)\end{array}$ & $\begin{array}{l}0.0075 * * * \\
(0.0015) \\
\end{array}$ \\
\hline ICT $\times$ dist. to market & & & & $\begin{array}{l}-0.0026^{* *} \\
(0.0013)\end{array}$ \\
\hline Dist. to extension agents' office & $\begin{array}{l}-0.0039 \\
(0.0033)\end{array}$ & $\begin{array}{l}-0.0033 * \\
(0.0019)\end{array}$ & $\begin{array}{l}-0.0035^{* * *} \\
(0.0016)\end{array}$ & $\begin{array}{l}-0.0042^{* *} \\
(0.0021)\end{array}$ \\
\hline Discount rate & $\begin{array}{l}0.0031 * * * \\
(0.0010)\end{array}$ & $\begin{array}{l}0.0029 * * * \\
(0.0011)\end{array}$ & $\begin{array}{l}0.0029 * * \\
(0.0012)\end{array}$ & $\begin{array}{l}0.0031 * * * \\
(0.0010)\end{array}$ \\
\hline No. of crops & $\begin{array}{l}-0.0169 \text { *** } \\
(0.0060)\end{array}$ & $\begin{array}{l}-0.0174 * * * \\
(0.0048)\end{array}$ & $\begin{array}{l}-0.0179 * * * \\
(0.0061)\end{array}$ & $\begin{array}{l}-0.0156^{* *} \\
(0.0061)\end{array}$ \\
\hline Constant & $\begin{array}{l}0.3296 * * * \\
(0.0925)\end{array}$ & $\begin{array}{l}0.3473 * * * \\
(0.0926)\end{array}$ & $\begin{array}{l}0.3419 * * * \\
(0.0784)\end{array}$ & $\begin{array}{l}0.3666 * * * \\
(0.1150\end{array}$ \\
\hline District dummies & Yes & Yes & Yes & Yes \\
\hline Wald chi2 test ( $p$-value) & 0.00 & 0.00 & 0.00 & 0.00 \\
\hline Root MSE & 0.111 & 0.111 & 0.111 & 0.111 \\
\hline Adjusted $R$-square & 0.20 & 0.15 & 0.15 & 0.21 \\
\hline$N$ & 400 & 400 & 400 & 400 \\
\hline
\end{tabular}

Notes: Standard errors are bootstrapped and clustered in seven kebeles (villages) $*, * *, * * *$ denote statistical significance at $10 \%, 5 \%$, and $1 \%$ level, respectively

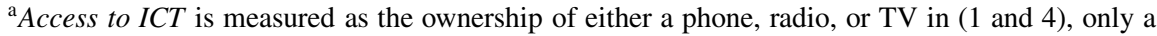
phone in (2), only a radio in (3) 
Open Access This chapter is distributed under the terms of the Creative Commons AttributionNoncommercial 2.5 License (http://creativecommons.org/licenses/by-nc/2.5/) which permits any noncommercial use, distribution, and reproduction in any medium, provided the original author(s) and source are credited.

The images or other third party material in this chapter are included in the work's Creative Commons license, unless indicated otherwise in the credit line; if such material is not included in the work's Creative Commons license and the respective action is not permitted by statutory regulation, users will need to obtain permission from the license holder to duplicate, adapt or reproduce the material.

\section{References}

Aker JC, Fafchamps M (2015) Mobile phone coverage and producer markets: evidence from West Africa. World Bank Econ Rev 29(2):262-292

Algieri B, Kalkuhl M (2014) Back to the futures: an assessment of commodity market efficiency and forecast error drivers. ZEF discussion papers no. 195, Bonn, Germany

Belay K, Abebaw D (2004) Challenges facing agricultural extension agents: a case study from South-western Ethiopia. Afr Dev Rev 16(1):139-168

Bellemare M, Barrett C, Just D (2013) The welfare impacts of commodity price volatility: evidence from rural Ethiopia. Am J Agric Econ 95(4):877-899

Binswanger HP, Rosenzweig MR (1986) Behavioural and material determinants of production relations in agriculture. J Dev Stud 22(3):503-539

Burbidge JB, Magee L, Robb AL (1988) Alternative transformations to handle extreme values of the dependent variable. J Am Stat Assoc 83(401):123-127

Cameron AC (2009) Advances in count data regression. Paper presented at the 28th annual workshop in applied statistics, Southern California Chapter of the American Statistical Association, University of California-Los Angeles

Cameron AC, Trivedi PK (2010) Microeconometrics using Stata, revised ed. Stata, College Station, TX

Chavas JP (2000) On information and market dynamics: the case of the US beef market. J Econ Dynam Contr 24(5-7):833-853

CSA (2012) Household consumption and expenditure (HCE) survey (2010/11). Analytical report, statistical report bulletin 394. Volume II, bulletin 563

Dercon S, Hoddinott J (2004) The Ethiopian rural household surveys: introduction. International Food Policy Research Institute (IFPRI), Washington, DC

Ezekiel M (1938) The Cobweb theorem. Q J Econ 52(2):255-280

Gardner BL (1976) Futures prices in supply analysis. Am J Agric Econ 58(1):81-84

Holt MT, McKenzie AM (2003) Quasi-rational and ex ante price expectations in commodity supply models: an empirical analysis of the US broiler market. J Appl Econometrics 18(4):407-426

Jensen R (2007) The digital provide: information (technology), market performance, and welfare in the South Indian fisheries sector. Q J Econ 122(3):879-924

Just RE, Rausser GC (1981) Commodity price forecasting with large-scale econometric models and the futures market. Am J Agric Econ 63(2):197-208

Labonne J, Chase RS (2009) The power of information: the impact of mobile phones on farmers' welfare in the Philippines. Policy research working paper 4996, World Bank

Mitchell T (2011) Middlemen, bargaining and price information: is knowledge power? Mimeo, London School of Economics

Moschini G, Hennessy DA (2001) Uncertainty, risk aversion, and risk management for agricultural producers. Handbook Agric Econ 1(A):88-153

Moss CB, Shonkwiler JS (1993) Estimating yield distributions with a stochastic trend and nonnormal errors. Am J Agric Econ 75(4):1056-1062 
Muth JF (1961) Rational expectations and the theory of price movements. Econometrica 29(3):315-335

Nakasone E, Torero M, Minten B (2014) The power of information: the ICT revolution in agricultural development. Annu Rev Resource Econ 6(1):533-550

Nerlove M (1958) Adaptive expectations and cobweb phenomena. Q J Econ 72(2):227-240

Nichols A (2010) Regression for nonnegative skewed dependent variables. Paper presented at the Stata Conference, Boston, MA

Orazem P, Miranowski J (1986) An indirect test for the specification of expectation regimes. Rev Econ Stat 68(4):603-609

Ramakrishna G, Demeke A (2002) An empirical analysis of food insecurity in Ethiopia: the case of North Wello. Afr Dev 27(1):127-143

Rashid S (2011) Intercommodity price transmission and food price policies: an analysis of Ethiopian cereal markets. International Food Policy Research Institute (IFPRI), Washington, DC

Santos Silva JS, Tenreyro S (2006) The log of gravity. Rev Econ Stat 88(4):641-658

Spielman DJ, Kelemwork D, Alemu D (2012) Seed, fertilizer, and agricultural extension in Ethiopia. In: Dorosh PA, Rashid S (eds) Food and agriculture in Ethiopia: progress and policy challenges. Pennsylvania Press, Philadelphia, PA, pp 346

Stigler GJ (1961) The economics of information. J Polit Econ 69(3):213-225

Svensson J, Yanagizawa D (2009) Getting prices right: the impact of the market information service in Uganda. J Eur Econ Assoc 7(2-3):435-445

Tack J, Aker JC (2014) Information, mobile telephony, and traders' search behavior in Niger. Am J Agric Econ 96(5):1439-1454

Tadesse G, Bahiigwa G (2015) Mobile phones and farmers' marketing decisions in Ethiopia. World Dev 68:296-307

Tadesse G, Guttormsen AG (2011) The behavior of commodity prices in Ethiopia. Agric Econ 42(1):87-97

Wooldridge JM (2010) Econometric analysis of cross section and panel data, 2nd edn. MIT Press, Cambridge, MA 